\title{
PENGARUH KEMANDIRIAN BELAJAR TERHADAP PRESTASI BELAJAR BAHASA INDONESIA PADA SISWA KELAS XI SMA DI KOTA DEPOK JAWA BARAT
}

\author{
Mia Widianti ${ }^{1}$, Mahmudah Nursolihah ${ }^{2}$, Nasaruddin ${ }^{3}$ \\ Program Studi Pendidikan Bahasa dan Sastra Indonesia \\ Sekolah Tinggi Keguruan dan Ilmu Pendidikan (STKIP) Pancakarya Tangerang \\ Surel: mia.widianti.mw@gmail.com
}

\begin{abstract}
ABSTRAK
Penelitian ini bertujuan untuk menguji teori dan model yang fit dengan data empiris mengenai masalah pengaruh kemandirian terhadap prestasi belajar Bahasa Indonesia kelas XI SMA Di Kota Depok Jawa Barat tahun ajaran 2015/2016. Metode yang digunakan penelitian ini adalah metode kuantitatif dengan pendekatan survey. Populasi penelitian adalah siswa SMA Negeri di Kota Depok Jawa Barat. Sampel penelitian ditentukan dengan teknik sampel acak proporsional sebanyak 306 siswa. Pengumpulan data menggunakan tes objektif dan kuesioner skala Model Likert. Data diperoleh berdasarkan kemampuan siswa menjawab soal Bahasa Indonesia dan kemandirian dalam belajar. Analisis data menggunakan Structural Equation Modeling (SEM), dengan bantuan program aplikasi LISREL 8.80. Hasil penelitian dari 2 variabel laten dan 9 variabel kontruk yang cocok dengan model yang diusulkan, diperoleh dari uji hipotesis berdasarkan nilai GAMMA memiliki standar loading sebesar 0.68 error sebesar 0.05 nilai t-hitung sebesar 12.62 bila dikonsultasikan dengan nilai $t_{\text {tabel }}$ dengan jumlah sampel > $100: \alpha 0.05$ maka diperoleh $t_{\text {tabel }}$ sebesar 1.96. karena $t_{\text {hitung }} 12.62>t_{\text {tabel }} 1.96$ maka dapat disimpulkan; kemandirian belajar berpengaruh secara signifikan terhadap prestasi belajar siswa mata pelajaran Bahasa Indonesia.
\end{abstract}

Kata Kunci: kemandirian belajar, terhadap prestasi belajar, bahasa Indonesia

\section{ABSTRACT}

This research aims to test the theory and model that fit the empirical data on the issue of selfreliance on the Indonesian language learning Achievement XI SMA class in Depok City West Java school year 2015/2016. The method used by this research is a quantitative method with a survey approach. The research population is high school students in Depok City of West Java. Research samples were determined by a proportional sample technique as much as 306 students. Data collection using objective tests and Model Likert scale questionnaires. Data obtained based on the ability of students to answer about Bahasa Indonesia and independence in learning. Data analysis uses Structural Equation Modeling (SEM), with the help of the LISREL 8.80 application program. The results of the study of 2 latent variables and 9 contractual variables matching the proposed model, obtained from the hypothesis test based on the GAMMA value had a standard loading of 0.68 error of $0.05 t$-count value of 12.62 when consulted With a value of the sample with a number of samples $>100: \alpha 0.05$ then obtained a this of 1.96. Because t count 12.62 > This 1.96 then can be concluded; Studies have significantly influenced the learning performance of students of Indonesian subjects.

Keywords: self-reliance Learning, learning achievement, language 


\section{PENDAHULUAN}

Prestasi belajar merupakan hal yang sangat penting dalam pendidikan karena menjadi salah satu alat ukur sejauh mana tingkat pemahaman siswa dalam memahami suatu materi. Hasil belajar yang baik berupa prestasi yang memuaskan merupakan harapan bagi siswa, orang tua siswa, dan juga guru, namun memperoleh prestasi belajar yang baik tidaklah mudah karena banyak faktor yang berpengaruh di dalamnya. Faktor siswa memegang peranan penting dalam pencapaian prestasi belajar, karena siswa yang melakukan kegiatan belajar perlu memiliki kemandirian belajar yang baik.

Melihat begitu pentingnya prestasi belajar dalam pendidikan, tentunya sekolah akan berusaha menghasilkan siswa-siswa yang memiliki prestasi yang memuaskan dalam setiap mata pelajaran termasuk mata pelajaran Bahasa Indonesia. Akan tetapi pada kenyataannya, di SMA yang berada di Depok JawaBarat, terjadi fenomena di mana tiga tahun terakhir ini masih ada juga siswa yang memperoleh nilai yang rendah pada mata pelajaran Bahasa Indonesia. Rendahnya nilai siswa ini dapat dilihat dari masih ada beberapa siswa yang nilainya berada di bawah Kriteria Ketuntasan Minimum (KKM), dimana Kriteria Ketuntasan Minimum (KKM) di SMA Negeri di Daerah Depok Jawa-Barat dari MGMP guru bidang studi sebesar 75 . Berikut jumlah siswa di kelas XI SMA Negeri di Depok mata pelajaran Bahasa Indonesia tiga tahun terakhir:

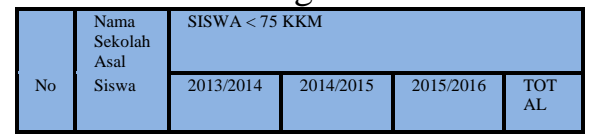

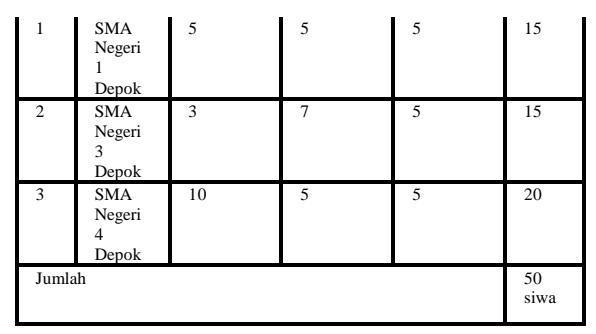

Sumber: Dokumen kurikulum dari hasil studi pendahulu dari guru bidang studi masing-masing sekolah.

Tabel 1. Data Prestasi Belajar Bahasa Indonesia Siswa Kelas XI SMA Negeri Kota Depok.

Berdasarkan permasalahan yang ada di atas, maka untuk meningkatkan prestasi siswa agar menjadi lebih baik salah satu faktor pendukungnya adalah kemandirian belajar. Kemandirian belajar dalam belajar juga sangat mempengaruhi siswa untuk mencapai keberhasilan dalam belajar. Tanpa kesadaran, kemauan, dan keterlibatan siswa, maka proses belajar tidak akan berhasil. Dengan demikian dalam belajar siswa dituntut memiliki kemaandirian, artinya siswa perlu memiliki kesadaran, kemauan dan dari dalam diri siswa dan bukan semata-mata tekanan orang pihak lain. Dengan adanya kemandirian dalam diri siswa, tujuan belajar akan berhasil dicapai sebagaimana yang diharapkan. Jadi kemandirian seseorang dalam belajar akan menentukan arah belajar danaerprestasi belajar seseorang. Kemandirian akan membuat seorang siswa mampu belajar sendiri tanpa disuruh oleh pihak luar dalam kondisi ujian atau tidak ujian. Kemandirian ini menekankan pada aktivitas dalam belajar yang penuh tanggungjawab sehingga mampu mencapai prestasi belajar yang tinggi.

Berdasarkan latar belakang masalah diatas, maka penulis tertarik untuk melakukan penelitian yang 
berjudul "Pengaruh Kemandirian Belajar Terhadap Prestasi Belajar Bahasa Indonesia pada Kelas XI SMA di Kota Depok Jawa-Barat".

Berdasarkan identifikasi masalah dan batasan masalah diatas, maka yang menjadi rumusan masalah dalam penelitian ini adalah: "Apakah terdapat Pengaruh Kemandirian Belajar Terhadap Prestasi Belajar Bahasa Indonesia pada Kelas XI SMA di Kota Depok Jawa-Barat?

\section{Prestasi Belajar}

Kata "Prestasi" berasal dari bahasa belanda yaitu prestatie. Kemudian dalam bahasa Indonesia menjadi "prestasi". yang berarti "hasil usaha". Istilah "prestasi belajar" (achievement) berbeda dengan "hasil belajar" (learning outcome). prestasi belajar pada umumnya berkenaan dengan aspek pengetahuan, sedangkan hasil belajar meliputi aspek pembentukan watak (Djamarah, 2011: 12). Prestasi dalam kamus Besar Bahasa Indonesia (2008: 895) adalah hasil yang telah dicapai (dari yang dilakukan, dikerjakan dan sebagainya). Dengan demikian belajar lebih ditekankan pada proses kegiatannya dan proses belajar lebih ditekankan pada hasil belajar yang dicapai oleh subjek belajar atau siswa. Hasil belajar dari kegiatan belajar disebut juga dengan prestasi belajar. Hasil atau prestasi belajar subjek belajar atau peserta didik dipakai sebagai ukuran untuk mengetahui sejauh mana peserta didik dapat menguasai bahan pelajaran yang sudah dipelajari.

Merujuk dari konsep diatas, apabila dikaitkan dengan mata pelajaran Bahasa Indonesia dapat disimpulkan bahwa prestasi belajar kemampuan siswa menjawab soal dari materi ajar yang terdapat dalam materi pelajaran. Kemampuan yang dimaksud adalah siswa mampu menjawab soal Bahasa Indonesia saat ujian akhir semester ganjil / genap tahun ajaran 2015/2016.

\section{Kemandirian Belajar}

Pada dasarnya pengertian mandiri itu dapat ditinjau dari dua segi, yaitu pengertian secara etimologi (bahasa) dan pengertian secara terminologi (istilah). Dalam kamus Besar Bahasa Indonesia kata "mandiri" mempunyai arti keadaan dapat berdiri sendiri, tidak bergantung pada orang lain. J.L.G.M. Drost S.J menyatakan bahwa kemandirian adalah keadaan kesempurnaan dan keutuhan kedua unsur (budi dan badan) dalam kesatuan pribadi. Dengan kata lain, manusia mandiri adalah pribadi dewasa yang sempurna (J.L.G.M. Drost S, J, 1998: 39). Enung Fatimah mendefinisikan mandiri berdiri diatas kaki sendiri dengan kemampuan seseorang untuk tidak bergantung dengan orang lain serta bertanggung jawab atas apa yang dilakukannya (Fatimah Enung, 2006:141) Kemandirian belajar seseorang menurut Samana dikutip oleh Syarifudin Huda adalah bagaimana ia mengatur serta mengendalikan kegiatan belajarnya atas dasar pertimbangan, keputusan dan tanggung jawabrsendiri. Kemandirian belajar merupakan keadaan kesiapan belajar siswa yang berasal dari dalam diri siswa untuk bertindak dan mereaksi terhadap obyek-obyek yang berhubungan dengan bagaimana seseorang menga-tur serta mengendalikan kegiatan belajarnya atas. Pertimbangan, keputusan dan tanggung jawab sendiri Syarifudin (2007, hlm.18). 
Uraian tersebut memberikan indikasi bahwa individu yang menerapkan kemandirian belajar akan mengalami perubahan dalam kebiasaan belajar, yaitu dengan cara mengatur dan mengorganisasikan dirinya sedemikian rupa sehingga dapat menentukan tujuan belajar, kebutuhan belajar, dan strategi yang digunakan dalam belajar yang mengarah kepada tercapainya tujuan yang telah dirumuskan. Menurut Boud, seperti dikutip Sahoo, kemandirian belajar siswa, dapat diukur dari bebarapa indikator antara lain: 1) Mengidentifikasi kebutuhan belajar; 2) Merumuskan tujuan bahan belajar; 3) Merencanakan kegiatan belajar; 4) Memanfaatkan guru lebih sebagai pembimbing dari pada pengajar; 5) Belajar melalui sumber belajar nonguru seperti bahan belajar mandiri, melaksanakan tes/ tugas mandiri, dapat belajar di luar institusi pendidikan (P.K. Sahoo, 1994: 8-9)

\section{METODE}

Metode penelitian ini menggunakan metode survey dengan Pendekatan Penelitian Multi Analisis. Fred N Karlinger (2006:661) berpendapat, "Penelitian survey yang dimaksud adalah bersifat menjelaskan hubungan kausal mengkaji populasi yang besar maupun kecil dengan menyeleksi serta mengkaji sampel yang dipilih".

1. Metode Pengumpulan Data

Menurut Sugiyono Pengumpulan data dalam penelitian memakai kuesioner yang merupakan teknik pengumpulan data yang dilakukan dengan cara memberi seperangkat pertanyaan atau pernyataan tertulis kepada responden untuk dijawabnya (Sugiyono, 2009:80). Data dikumpulkan dengan menggunakan pertanyaan tertutup dengan menggunakan skala model likert yang terdiri dari 1- 4 pilihan jawaban terdiri dari; Selalu $(\mathrm{SL})=4$, Sering $(\mathrm{SR})=3$, Kadang-Kadang $(\mathrm{KD})=2$, Tidak pernah (TP) - 1. Untuk variabel prestasi belajar sejarah menggunakan tes soal pilihan ganda disediakan 1 jawaban yang benar dari 5 pilihan jawaban. a, b, c, d, e.

\section{Populasi dan Sampel}

Populasi target dalam penelitian ini adalah seluruh siswa kelas XI SMA Negeri di Daerah Depok jawa-Barat. Untuk populasi terjangkau seluruh siswa/siswi kelas XI di tiga SMA Negeri yaitu SMA Negeri 1 Depok, SMA Negeri 3 Depok dan SMA Negeri 4 Depok. Tahun Pelajaran 2015/2016 sebanyak 1320 orang siswa. Adapun dalam penelitian ini peneliti mengambil jumlah sampel dengan menggunakan rumus Slovin dengan batas toleransi kesalahan sebesar $5 \%$.

$$
\begin{aligned}
& \mathrm{n}=\quad \frac{N}{1+N(e)^{2}}= \\
& \frac{1320}{1+1320(0.05)^{2}}=306 \\
& \text { jadi jumlah sampel sebanyak } \\
& 306 \text { siswa diambil secara } \\
& \text { random. } \\
& \text { 3. } 3 \text {, Operasional Variabel Peneli- } \\
& \text { tian }
\end{aligned}
$$
Ilmiah random.
idikan Bahasa,

Untuk mengukur variabel prestasi belajar diukur dengan 50 item soal berbentuk pilihan ganda meliputi:

1) ujian tengah semester ganjil diberi simbol $\left(\mathrm{Y}^{1}\right)$;

2) ujian akhir semester ganjil diberi simbol $\left(\mathrm{Y}^{2}\right)$;

3) ujian tengah semester genap diberi simbol $\left(\mathrm{Y}^{3}\right)$ 
4) ujian akhir semester genap diberi simbol $\left(\mathrm{Y}^{4}\right)$.

Setiap jawaban yang benar di beri skor 1, dan apabila jawaban salah di beri skor 0 dan skor total jawaban ditansformasikan kedalam rumus: $\mathrm{Y}=$ $\mathrm{n} / \mathrm{N} \quad \mathrm{x} 5$ dimana; $\mathrm{Y}=$ skor kemampuan peserta tes, $\mathrm{n}=$ jumlah jawaban yang benar dan $\mathrm{N}=$ jumlah item soal, $5=$ skala acuan. Misalnya peserta menjawab benar sebanyak 40 item, maka $\mathrm{Y}=40 / 50 \times 5=4$. Untuk mengukur variabel Kemandirian Belajar Siswa, diukur dengan 5 item pernyataan berikut:

1) Mengidentifikasi kebutuhan belajar diberi symbol $\left(\mathrm{x}^{1}\right)$

2) Merumuskan tujuan bahan belajar diberi symbol $\left(\mathrm{x}^{2}\right)$

3) Merencanakan kegiatan belajar diberi symbol (X3)

4) Memanfaatkan guru sebagai pembimbing diberi symbol (X4)

5) Belajar melalui berbagai sumber diberi symbol (X5)

Setiap pernyataan memiliki bobot skor jawaban $1-5$.

\section{A. Teknik Analisa Data}

Analisis data berdasarkan konsep SEM yaitu analisis full model structural. Oleh karena itu dalam analisa data digunakan teknik analisa SEM dengan bantuan aplikasi LISREL 8.80. Analisis dengan SEM digunakan untuk penelitian ini dibutuhkan untuk memperoleh model struktural yang fit. Ketentuan pengujian model apabila model tidak memenuhi kriteria model good fit index maka model perlu modifikasi. Untuk pengujian model didasari pada nilai pada tabel berikut:

Tabel 2 Good Of Fit Index

\begin{tabular}{|c|c|c|c|}
\hline No & $\begin{array}{l}\text { Good Of Fit } \\
\text { Index }\end{array}$ & Cut Off Value & Criteria \\
\hline 1 & $\begin{array}{l}\text { Chi-Square } \\
\text { Probability }\end{array}$ & $<\alpha$. df $<0,05$ & Over Identified \\
\hline 2 & $\begin{array}{l}\text { Root Mean } \\
\text { Square Error of } \\
\text { Approximation } \\
\text { (RMSEA) }\end{array}$ & $\leq 0,08$ & Good Fit \\
\hline 3 & $\begin{array}{l}\text { Root Mean } \\
\text { Square } \\
\text { Residual } \\
\text { (RMR) }\end{array}$ & $\geq 0.08$ & \\
\hline 4 & $\begin{array}{l}\text { Goodness of } \\
\text { Fit Index (GFI) }\end{array}$ & $\geq 0.90$ & Good Fit \\
\hline 5 & \begin{tabular}{l}
\multicolumn{3}{c}{ Adjusted } \\
Goodness of \\
Fit Index \\
$($ AGFI)
\end{tabular} & $\geq 0.90$ & Good Fit \\
\hline 6 & \begin{tabular}{l}
\multicolumn{2}{l}{ Parsimony } \\
Goodness of \\
Fit Index \\
(PGFI) \\
\end{tabular} & $>0,05$ & Good Fit \\
\hline 7 & $\begin{array}{l}\text { Normed Fit } \\
\text { Index (NFI) }\end{array}$ & $\geq 0.90$ & Good Fit \\
\hline 8 & $\begin{array}{ll}\begin{array}{l}\text { Non-Normed } \\
\text { Fit Index } \\
(\mathrm{NNFI})\end{array} \\
\end{array}$ & $\geq 0.90$ & Good Fit \\
\hline 9 & $\begin{array}{l}\text { Parsimony } \\
\text { Normed Fit } \\
\text { Index (PNFI) }\end{array}$ & $\geq 0.90$ & Good Fit \\
\hline $\begin{array}{l}\text { sallasa, } \\
10 \text { Daerd }\end{array}$ & \begin{tabular}{|l|} 
OSTrOa \\
Comparative \\
Fit Index (CFI) \\
\end{tabular} & $\geq 0.90$ & Good fit \\
\hline 11 & $\begin{array}{l}\text { Incremental Fit } \\
\text { Index (IFI) }\end{array}$ & $\geq 0.90$ & Good fit \\
\hline 12 & $\begin{array}{l}\text { Relative Fit } \\
\text { Index (RFI) }\end{array}$ & $\geq 0.90$ & Good fit \\
\hline
\end{tabular}

\section{B. Analisis Hasil Temuan}

1. Validitas Item

Uji validitas item dengan tujuan untuk mengetahui apakah item kuisioner yang digunakan sebagai alat ukur memiliki validitas (ketepatan) yang baik atau tidak. 


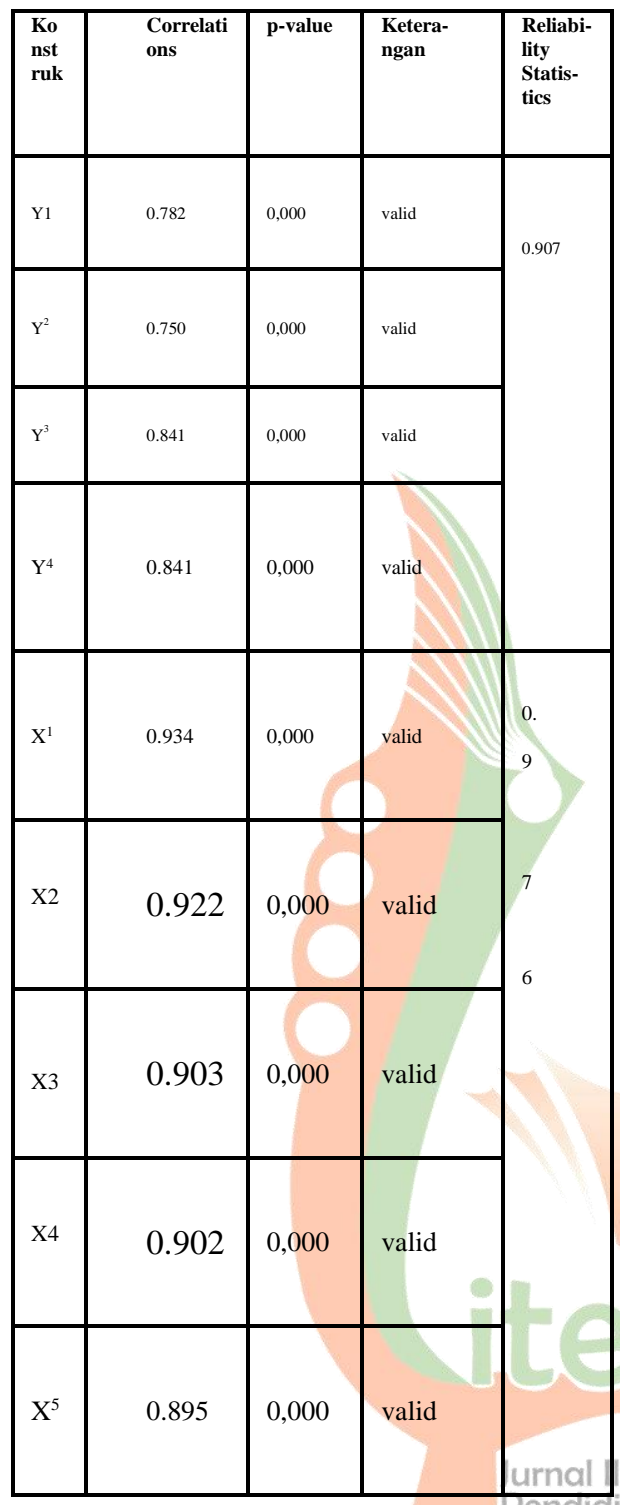

Tabel 1. Hasil Validitas dan Realibilitas Item

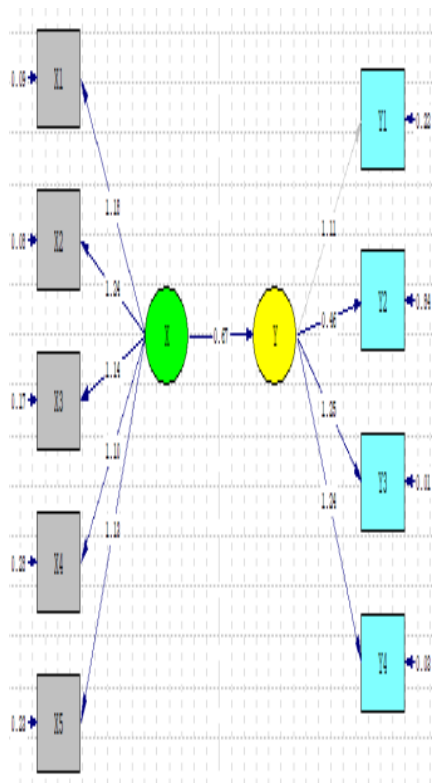

Gamabar 1. Hasil Estimasi Model

2. LAMBDA-Y

LAMBDA-Y merupakan yang menunjukkan pengaruh dan tingkat Signifikansi konstruk latent dependent terhadap variabel kontruk atau variabel manifest LISREL Estimates (Maximum Likelihood)

\section{LAMBDA-Y}

Y

$\begin{array}{ll}\mathrm{Y} 1 & 1.11\end{array}$

Y2 0.46

$(0.05)$

$\mathrm{Y}^{\mathrm{ah}} 1.24$

40.86

Y4 1.23

(0.03)

39.75

Dari persamaan di atas menunjukan data Y1 = ujian tengah semester ganjil error dari variabel manifest. Y2 = ujian akhir semester ganjil memiliki nilai standar loading sebesar 0.46 error 
sebesar 0.05 nilai t-hitung sebesar 8.53. $\mathrm{Y} 3$ = ujian tengah semester genap memiliki nilai standar loading sebesar 1.24 error sebesar 0.03 nilai t-hitung sebesar 40. 86. Y4 = ujian akhir semester genap memiliki nilai standar loading sebesar 1.23 error sebesar 0.03 nilai t-hitung sebesar 39. 75 .

\section{LAMBDA-X}

LAMBDA-X merupakan yang menunjukkan pengaruh dan tingkat signifikansi kontruk latent independent terhadap variabel kontruk atau variabel manifest

\begin{tabular}{|c|c|}
\hline & $X$ \\
\hline $\mathrm{X} 1$ & 1.18 \\
\hline & $(0.05)$ \\
\hline & 23.24 \\
\hline $\mathrm{X} 2$ & 1.24 \\
\hline & $(0.05)$ \\
\hline & 23.45 \\
\hline X3 & 1.14 \\
\hline & $(0.05)$ \\
\hline & 21.88 \\
\hline $\mathrm{X} 4$ & 1.10 \\
\hline & $(0.05)$ \\
\hline & 20.31 \\
\hline$\times 5$ & 1.13 \\
\hline & $(0.05)$ \\
\hline & 21.13 \\
\hline
\end{tabular}

Dari persamaan di atas menunjukan data $\mathrm{X} 1=$ Identifikasi kebutuhan belajar memiliki standar loading sebesar 1.18 error sebesar 0.05 nilai t-hitung sebesar 23.24. $\mathrm{X} 2=$ Merumuskan tujuan bahan belajar memiliki standar loading sebesar 1.24 error sebesar 0.05 nilai t-hitung sebesar 23.45. $\mathrm{X} 3=$ Merencanakan kegiatan belajar memiliki standar loading sebesar 1.14 error sebesar 0.05 nilai t-hitung sebesar 21.88. $\mathrm{X} 4=$ memanfaatkan guru sebagai pembimbing memiliki standar loading sebesar 1.10 error sebesar 0.05 nilai t-hitung sebesar 20.31. X5 = Belajar melalui berbagai sumber memiliki standar loading sebesar 1.13 error sebesar 0.05 nilai t-hitung sebesar 21.13

\section{GAMMA}

GAMMA merupakan yang menunjukkan pengaruh dan tingkat signifikansi konstruk latent independent terhadap kontruk latent dependent

$$
\begin{array}{cc} 
& \mathrm{X} \\
\mathrm{Y} & 0.68 \\
& (0.05)
\end{array}
$$

$\mathrm{X}=$ kemandirian belajar siswa memiliki standar loading sebesar 0.68 error sebesar 0.05 nilai t-hitung sebesar 12.62 bila dikonsultasikan dengan nilai $t_{\text {tabel }}$ dengan jumlah sampel $>100$ : $\alpha 0.05$ maka diperoleh $\mathrm{t}_{\text {tabel }}$ sebesar 1.96. karena $\mathrm{t}_{\text {hitung }}$ $12.62>\mathrm{t}_{\text {tabel }} 1.96$ maka dapat disimpulkan; kemandirian belajar (X) berpengaruh secara signifikan terhadap prestasi belajar siswa mata pelajaran Bahasa indonesia (Y).

\section{Struktural Equations}

Structural Equations merupakan matriks yang menunjukkan bentuk persamaan antara variabel laten dengan variabel.

Measurement Equations

\subsection{5}

$\mathrm{Y} 1=1.11 * \mathrm{Y}$, Errorvar. $=0.22, \mathrm{R}^{2}=$ (0.018)

11.92

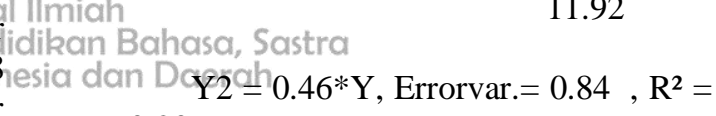
0.20
$(0.054)$
(0.068)
8.53
12.33
$\mathrm{Y} 3=1.25 * \mathrm{Y}$, Errorvar $=0.010, \mathrm{R}^{2}=$ 0.99

$\begin{array}{ll}(0.031) & (0.0056) \\ 40.86 & 1.86\end{array}$
0.98

$\mathrm{Y} 4=1.24 * \mathrm{Y}$, Errorvar. $=0.029, \mathrm{R}^{2}=$ 
$(0.031) \quad(0.0059)$

$39.75 \quad 4.87$

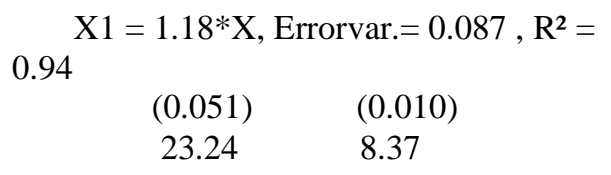

$\mathrm{X} 2=1.24 * \mathrm{X}$, Errorvar. $=0.081, \mathrm{R}^{2}=$ 0.95

$\begin{array}{ll}(0.053) & (0.011) \\ 23.45 & 7.66\end{array}$

$\mathrm{X} 3=1.14 * \mathrm{X}$, Errorvar. $=0.17, \mathrm{R}^{2}=$ 0.88

$\begin{array}{cc}(0.052) & (0.016) \\ 21.88 & 10.56\end{array}$

$\mathrm{X} 4=1.10 * \mathrm{X}$, Errorvar. $=0.28, \mathrm{R}^{2}=$ 0.81
(0.054)
(0.025)
20.31
11.34

$\mathrm{X} 5=1.13 * \mathrm{X}$, Errorvar. $=0.23, \mathrm{R}^{2}=$ 0.85

(0.053)

$(0.021)$

21.13

11.02

Structural Equations 0.45

$\mathrm{Y}=0.67 * \mathrm{X}$, Errorvar. $=0.55, \mathrm{R}^{2}=$

$$
\begin{array}{ll}
(0.053) & (0.052) \\
12.62 & 10.48
\end{array}
$$

Dari persamaan Structural Equations di atas bahwa nilai koefisien regresi $\mathrm{X}_{\mid} \|_{\| \text {miah }}$ atas Y sebesar 0.67, standar error sebesaridikan Bahasa, Sastra 0.053 , nilai uji - t sebesar 12.62 dan nilai esia dan Daerah koefisien determinasi atau $\mathrm{R}^{2}=0.45$. ini dimaknai, diasumsikan bahwa, jika kemandirian belajar (X) ditingkatkan sebesar 1 poin, maka prestasi belajar (Y) akan meningkat sebesar $67 \%$. kemudian dari nilai $\mathrm{R}^{2}=0.45$ yang dimaknai kemandirian belajar dapat menerangkan prestasi belajar sebesar $45 \%$

\section{Goodness of Fit Statistics}

Goodness of fit dari model statistik menggambarkan seberapa baik itu cocok dengan serangkaian pengamatan. Ukuran goodness of fit biasanya meringkas perbedaan antara nilai yang diamati dan nilai yang diharapkan dalam model tersebut. Model yang diususlkan seperti pada tabel good fit. Berikut hasil output lisrel Goodness of Fit Statistics data hasil penelitian.
Goodness of Fit Statistics

Degrees of Freedom $=$ 18

Minimum

Fit Function ChiSquare $=285.76(\mathrm{P}=$ 0.0 )

Normal Theory Weighted Least

Squares Chi-Square $=$ $193.94(\mathrm{P}=0.0)$

Non-centrality

Estimated

Parameter (NCP) = 175.94

90 Percent

Confidence Interval for $\mathrm{NCP}=(134.88$; 224.47)

Minimum Fit Function Value $=0.94$

Population

Discrepancy Function

Value $(\mathrm{F} 0)=0.58$

90 Percent

Confidence Interval

for $\mathrm{F} 0=(0.44 ; 0.74)$

Root Mean

Square Error of 
Approximation

$($ RMSEA $)=0.18$

90 Percent

Confidence Interval for $\mathrm{RMSEA}=(0.16$;

0.20 )

P-Value for

Test of Close Fit

$($ RMSEA $<0.05)=$

0.00

\section{Expected}

Cross-Validation

Index $(\mathrm{ECVI})=0.81$

90 Percent

Confidence Interval

for $\mathrm{ECVI}=(0.68$;

0.97 )

ECVI

for Saturated Model = 0.30

ECVI

for Independence

Model $=19.29$

Chi-Square

for

Independence Model with

36 Degrees of Freedom = 5866.18

Independence AIC = 5884.18

Model AIC $=247.94$

Saturated AIC $=90.00$

Jurnal Ilmiah

Independence CAIC-fidikan Bahasa, Sastra 5926.69

Model CAIC $=375.48$

Saturated CAIC = 302.56

Normed Fit Index $(\mathrm{NFI})=0.95$
Non-

Normed Fit Index

$(\mathrm{NNFI})=0.91$

Parsimony Normed Fit

Index $(\mathrm{PNFI})=0.48$

Comparative Fit Index $(\mathrm{CFI})=0.95$

Incremental Fit Index $(\mathrm{IFI})=0.95$

Relative Fit Index $($ RFI $)=0.90$

Critical $\mathrm{N}(\mathrm{CN})=$ 38.15

Root

Mean Square Residual $(\mathrm{RMR})=0.18$

Standardized RMR = 0.15

Goodness of Fit Index $(\mathrm{GFI})=0.90$

Adjusted

Goodness of Fit Index $(\mathrm{AGFI})=0.69$ 


\begin{tabular}{|c|c|c|c|c|}
\hline No & Good Of Fit Index & Results & $\begin{array}{l}\text { Cut } \\
\text { Value }\end{array}$ & Criteria \\
\hline 1 & $\begin{array}{lr}\begin{array}{l}\text { Minimum } \\
\text { Function } \\
\text { Square }\end{array} & \text { Fit } \\
\end{array}$ & 285.76 & $\begin{array}{l}\text { df: } \alpha 0.05= \\
<128.8039 \\
\end{array}$ & Good Fit \\
\hline 2 & $\begin{array}{l}\text { Root Mean Square } \\
\text { Error } \\
\text { Approximation of } \\
\text { (RMSEA) } \\
\end{array}$ & 0.18 & $\leq 0,05$ & Marginal Fit \\
\hline 3 & $\begin{array}{l}\text { Root Mean Square } \\
\text { Residual (RMR) }\end{array}$ & 0.18 & $\geq 0.08$ & Goog fit \\
\hline 4 & $\begin{array}{l}\text { Goodness of Fit } \\
\text { Index (GFI) }\end{array}$ & 0.90 & $\geq 0.90$ & Good Fit \\
\hline 5 & $\begin{array}{l}\text { Adjusted Goodness } \\
\text { of Fit Index (AGFI) }\end{array}$ & 0.69 & $\geq 0.90$ & Marginal Fit \\
\hline 6 & $\begin{array}{l}\text { Parsimony } \\
\text { Goodness of Fit } \\
\text { Index (PGFI) } \\
\end{array}$ & 0.35 & $>0,05$ & Good Fit \\
\hline 7 & $\begin{array}{l}\text { Normed Fit Index } \\
\text { (NFI) }\end{array}$ & 0.95 & $\geq 0.90$ & Good Fit \\
\hline 8 & $\begin{array}{l}\text { Non-Normed } \\
\text { Index (NNFI) }\end{array}$ & 0.95 & $\geq 0.90$ & Good Fit \\
\hline 9 & $\begin{array}{l}\text { Parsimony Normed } \\
\text { Fit Index (PNFI) }\end{array}$ & 0.48 & $\geq 0.90$ & Marginal Fit \\
\hline 10 & $\begin{array}{l}\text { Comparative } \quad \text { Fit } \\
\text { Index }(\mathrm{CFI})\end{array}$ & 0.95 & $\geq 0.90$ & Good fit \\
\hline 11 & $\begin{array}{l}\text { Incremental } \quad \text { Fit } \\
\text { Index (IFI) }\end{array}$ & 0.95 & $\geq 0.90$ & Good fit \\
\hline 12 & $\begin{array}{l}\text { Relative Fit Index } \\
\text { (RFI) }\end{array}$ & 0.95 & $\geq 0.90$ & Good fit \\
\hline
\end{tabular}

Parsimony

Goodness of Fit Index

$(\mathrm{PGFI})=0.35$

Tabel 3. Hasil Uji Good Of Fit Index

$$
\begin{gathered}
C R y=\frac{(3.31)^{2}}{(3.31)^{2}+0.116}=\frac{10.95}{11.07} \\
=0.98
\end{gathered}
$$

Hasil perhitungan nilai $\mathrm{CR}$ kontruk prestasi belajar sebesar $0.98>0.70$. sehingga disimpulkan kuntruk prestasi belajar siswa memiliki tingkat derajad yang baik (realible). Kemudian untuk CR kemandirian belajar siswa sebagai berikut:

$$
\begin{gathered}
C R x=\frac{(6.71)^{2}}{(6.71)^{2}+0.26}=\frac{45.02}{45.28} \\
=0.99
\end{gathered}
$$

Hasil perhitungan nilai CR kontrukkemandirian belajar sebesar 0.99 $>$ 0.70. sehingga disimpulkan kuntruk kemandirian belajar siswa memiliki tingkat derajad yang baik (realible). Kemudian variance extracted kontruk prestasi belajar dan kemandirian belajar sebagai berikut:

$$
\begin{gathered}
V E y=\frac{4.06^{2}}{4.06^{2}+0.116}=\frac{16.48}{16.59} \\
=0.99
\end{gathered}
$$

$$
V E x=\frac{5.79^{2}}{5.79^{2}+0.26}=\frac{33.52}{33.78}=0.99
$$

Hasil perhitungan nilai VE kontruk prestasi belajar dan kemandirian belajar siswa memiliki nilai sebesar $0.99>0.50$. sehingga disimpulkan kuntruk prestasi belajar, dan kemandirian belajar siswa memilikihkeunikan dan dapat mengukur fenomena yang diukur.

\section{Uji Hipotesis}

$$
\begin{aligned}
& \text { Ho : } \rho=0 \\
& \text { H1 : } \rho \neq 0
\end{aligned}
$$

Dari hasil perhitungan pada nilai GAMMA di atas diperoleh nilai

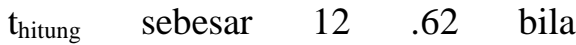
dikonsultasikan dengan nilai $t_{\text {tabel }}$ dengan jumlah sampel $>100: \alpha 0.05$ 
maka diperoleh $\mathrm{t}_{\text {tabel }}$ sebesar 1.96 . karena $t_{\text {hitung }} 12.62>t_{\text {tabel }} 1.96$ dengan demikian Ho ditolak, maka dapat disimpulkan; bahwa kemandirian belajar berpengaruh secara sigifikan terhadap prestasi Belajar Bahasa Indonesia pada Kelas XI SMA di Kota Depok Jawa-Barat

\section{PEMBAHASAN}

Kemandirian belajar berpengaruh secara signifikan terhadap prestasi belajar siswa hasil temuan ini memperkuat teori Boud yang dikutip Sahoo, kemandirian belajar siswa, dapat diukur dari bebarapa indikator antara lain: 1) Mengidentifikasi kebutuhan belajar; 2) Merumuskan tujuan bahan belajar; 3) Merencanakan kegiatan belajar; 4) Memanfaatkan guru lebih sebagai pembimbing dari pada pengajar; 5) Belajar melalui sumber belajar nonguru seperti bahan belajar mandiri, melaksanakan tes/ tugas mandiri, dapat belajar di luar institusi pendidikan misalnya di tempat kerja atau di rumah (P.K. Sahoo, 1994, 8-9). J.L.G.M. Drost S.J menyatakan bahwa kemandirian adalah keadaan kesempurnaan dan keutuhan kedua unsur (budi dan badan) dalam kesatuan pribadi. Dengan kata lain, manusia mandiri adalah pribadi dewasa yang sempurna (J.L.G.M. Drost S, J. 1998:39). Mandiri berdiri diatas kaki sendiri dengan kemampuan seseorang untuk tidak bergantung dengan orang lain serta bertanggung jawab atas apa yang dilakukannya (Fatimah Enung, 2006: 141). Kemandirian belajar seseorang mengatur serta mengendalikan kegiatan belajarnya atas dasar pertimbangan, keputusan dan tanggung jawab sendiri. Kemandirian belajar merupakan keadaan kesiapan belajar siswa yang berasal dari dalam diri siswa untuk bertindak dan mereaksi terhadap obyek-obyek yang berhubungan dengan bagaimana seseorang mengatur serta mengendalikan kegiatan belajarnya atas. Pertimbangan, keputusan dan tanggung jawab sendiri. (Huda Syarifudin, 2007).

\section{SIMPULAN}

Dengan memperhatikan nilai faktor loading standard masingmasing indikator dalam fit model yang dihasilkan dalam penelitian ini, maka dapat diketahui standard loading mana yang relatif rendah dibanding yang lainnya. Indikator - indikator faktor loading standard yang relatif rendah yang menjadi fokus perhatiaan bagi guru bidang studi dan guru bimbingan konseling dan orangtua dalam rangka menemukan langkah yang tepat dalam memperbaiki prestasi belajar siswa. Dari beberapa indikator-indikator yang memiliki nilai standard loading kategori rendah bila dibanding dengan nilai standard loading lain. Adapun saran atau masukan berdasarkan kasus ini sebagai berikut:

a. Bagi guru bidang studi. Memperbaiki proses belajar mengajar dengan cara mengadakan ulangan harian menjelang ujian akhir semester

b. Bagi guru BK. Membuat program mingguan dalam rangka melakukan bimbangan dan konseling pada siswa, agar siswa memahami kelemahan dan kelebihan dirinya serta 
selalu berpikir positif dalam menghadapi setiap permasalahan yang dianggap sulit bagi siswa.

c. Saran bagi pembaca dan peneliti selanjutnya untuk melakukan kritikan, masukan dan melakukan penelitian ulang (replikasi) guna menyempurnakan hasil penelitian ini dan untuk menambah hasanah keilmuan.

\section{DAFTAR PUSTAKA}

Djamarah. 2011. Psikologi Belajar. Jakarta: Rineka Cipta.

Fatimah Enung, 2006. Psikologi Perkembangan Perkembangan Peserta Didik. Bandung: Pustaka Setia.

Fredn Karlinger, 2006. Asas-asas Penelitian Behavioral, Jogjakarta: Gajah Mada University Press.

Huda S yarifudin. 2007. Hubungan Konsep Diri dengan Kemandirian
Belajar Siswa Kelas VIII SMP N 3 Weru, Skripsi. Semarang: IKIP PGRI, Fakultas Ilmu Pendidikan Program Studi Bimbingan dan Konseling.

J.L.G.M. Drost S, J. 1998. Sekolah : Mengajar atau Mendidik, Jakarta: Konislun.

P.K. Sahoo, 1994. Open Learning System (New Delhi : Uppal Publishing House).

Pusat Bahasa DEPDIKNAS. 2008. Kamus Besar Bahasa Indonesia, Jakarta: Balai Pustaka.

Sugiyono, 2009. Metode penelitian kuantitatif, kualitatif dan R\&D. Bandung: Alfabeta.

Suseno, Bimo. 208. Uji Construct Reliability dan Variance Extracted Pada Model Structural Equation Modeling. Diakses 23 Oktober 2019 dilaman: http://www.statistikolahdata.co $\mathrm{m} / 2018 / 06 /$ uji-constructreliability-dan-variance.html. 